\title{
INVESTIGACIÓN
}

\section{Optimum conditions for enzymatic degradation of some oilseed proteins}

\author{
By FS Taha ${ }^{\star 1}$, MA Ibrahim ${ }^{1}$ and EA El-Zanaty ${ }^{2}$ \\ ${ }^{1}$ Fats and Oils Department. ${ }^{2}$ Pilot Plant and Chemical Engineering Department. \\ National Research Center, Cairo, Egypt.
}

\section{RESUMEN}

\begin{abstract}
Condiciones óptimas para la degradación enzimática de proteínas de semillas oleaginosas.
\end{abstract}

Proteínas de haba de soja, semilla de sésamo y harina de gérmen de arroz se hidrolizaron con dos enzimas, denominadas, papaina y bromelaina. Se han llevado a cabo experimentos para determinar las condiciones óptimas de cada enzima cuando actuan separadamente sobre cada sustrato. Los resultados mostraron que las mayores actividades relativas para la papaina se consiguieron con una $\mathrm{E} / \mathrm{S} 0,06,0,29,0,19$ y un $\mathrm{pH} 7.2,7.0,7.0$ para las proteínas de haba de soja, sésamo y harina de gérmen de arroz, respectivamente. La temperatura óptima para la papaina durante la hidrólisis de los tres sustratos fue de $50^{\circ} \mathrm{C}$. Cuando se usa bromelaina las relaciones E/S óptimas que proporcionaron mayor actividad relativa fueron $0.067,0.058$ y 0.21 para las proteínas de habas de soja, sésamo y harina de gérmen de arroz respectivamente. El pH óptimo fue 6.0 y la temperatura óptima $45^{\circ} \mathrm{C}$ para la bromelaina cuando se hidroliza la proteína de los tres sustratos. Con estos datos se hizo una correlación numérica del comportamiento enzimático para los diferentes sustratos.

PALABRAS-CLAVE: Bromelaina - Hidrólisis enzimática Papaina - Semilla oleaginosa.

\section{SUMMARY}

Optimum conditions for enzymatic degradation of some oilseed proteins.

Soybean, sesame seed, and rice bran meal proteins were hydrolyzed with two enzymes, namely, papain and bromelain . Experiments were carried out to elucidate the optimum condition for each enzyme when acting on each substrate separately. Results revealed that the highest relative activities for papain were achieved with $\mathrm{E} / \mathrm{S} 0.06,0.29,0.19$ and $\mathrm{pH} 7.2,7.0,7.0$ for soybean, sesame, and rice bran meal proteins, respectively. Optimum temperature for papain while hydrolysing the three substrates was $50^{\circ} \mathrm{C}$. When using bromelain optimum $E / S$ resulting in highest relative activities were $0.067,0.058$ and 0.21 for soybean, sesame, and rice bran meal protein, respectively. Optimum pH was 6.0 and optimum temperature was $45^{\circ} \mathrm{C}$ for bromelain when hydrolysing the protein of the three substrates. A numerical correlation of enzymatic behaviour for the different substrates was calculated. Papain

KEY-WORDS: Bromelain - Enzymatic hydrolysis - Oilseeds -

\section{INTRODUCTION}

The enzymatic hydrolysis of proteins from different sources to improve their solubility, digestibility and other functional properties has been well established (1-3). The improvement of the functional properties enables the protein to be successfully incorporated into many food systems. Proteolytic enzymes from animal plant,and microbial origin (1-5) have been utilized on different substrates, such as soybean (6-9), cottonseed (1), peanut (3), sesame $(10,11)$, and sunflower (8).

Protein hydrolysates used in nutritional formulations are generally categorized into two broad categories, partially hydrolyzed and extensively hydrolyzed proteins. Each category possess different properties that influence their utilization in the final product. Presently there are no precise, widely accepted specifications to differentiate the protein hydrolysates on chemical basis. Extensively hydrolyzed proteins have substantially reduced immunological reactivities and are primarily used in hypoallergenic formulas, because of the need to almost completely eliminate their allerginicity to avoid sensitization of individuals consuming them (12). These protein hydrolysates are usually comprised of amino acids and very short peptides (di and tri peptides).

The aim of the present investigation was to elucidate the optimum conditions for the enzymatic hydrolysis of soybean, sesame seed and rice bran meal protein, with two enzymes one of plant origin papain, and bromelain . The numerical correlation of enzymatic behaviour for different substrates was also elucidated. The results of this investigation will be the key to further work on partial degradation of these proteins.

\section{MATERIALS AND METHODS}

\subsection{Materials}

\subsubsection{Oilseed meals}

Soybean (glycine max) and sesame (Sesanum indicum) were supplied by the Research Institute of Field Crops, Ministry of Agriculture, Cairo, Egypt. 
Rice bran (Oryza sativa) was obtained from a local rice mill.

Soybeans and sesame seeds were dehulled and ground then subjected to several extractions with n-hexane to extract the oil. After two extractions, the meats are regrounded and extraction continued until residual oil in the meals did not exceed $1 \%$. Rice bran meal was prepared in the same manner but excluding the dehulling step. The defatted meals were spread to dry at room temperature and then ground and seived to pass an 80 mesh screen.

\subsubsection{Enzymes}

- Papain: DIFCO LABORATORIES (MICHIGAN USA), activity of papain while carrying experiments was 8.9 units $/ \mathrm{mg}$, unit as $\mu \mathrm{g}$ tyrosine released from casein $/ \mathrm{min} / \mathrm{mg}$.

- Bromelain: A product of SIGMA (Misouri USA), activity of bromelain while carrying the experiments was 27.6 unit $/ \mathrm{mg}$, unit as $\mu \mathrm{g}$ tyrosine released from casein/ $\mathrm{min} / \mathrm{mg}$. All reagents were of analytical grade.

\subsection{Methods}

\subsubsection{Determination of relative activity}

To a $250 \mathrm{ml}$ beaker that was placed in a thermostatic water bath,were added $100 \mathrm{ml}$ water and a weight of meal to containing $5 \mathrm{~g}$ protein. The mixture was continuously stirred with an electric stirrer and the $\mathrm{pH}$ and temperature adjusted to desired values. The reaction was carried on for 30 minutes while stirring and the $\mathrm{pH}$ and temperature maintained at the at previously adjusted values. The reaction was stopped by the addition of 0.5M TCA, and the hydrolysate filtered through Whatman no. 4, the residue washed with distilled water until an approximate volume of $250 \mathrm{ml}$ was collected. Aliquots of the filtrate were analyzed for total protein using the kjeldahl method and the relative activity was calculated as follows:

Relative activity $(\mathrm{RA})=\frac{\mathrm{Cp}-\mathrm{Hp}}{\mathrm{Cp}} \times 100$

Where: $\mathrm{Hp}$ is total protein obtained in enzyme assay

$\mathrm{Cp}$ is total protein in original meal ( control).

\subsubsection{Determination of the optimum conditions for the proteolytic activity of the enzymes}

This was accomplished through a series of experiments.

In the first set of experiments the enzyme papain was used together with sodium sulphite (which acts as an activator for papain ) on the three oilseed meals. The relative activity was determined by kjeldahl as mentioned above.

The first investigated criteria was the E/S ratio which is the ratio of concentration of enzyme to concentration of substrate. The E/S investigated ranged between 0.01 to 1.83 . The temperature and $\mathrm{pH}$ were those recommended by the manufacturer, and the experiment was carried as for determination of relative activity.

The $\mathrm{pH}$ was the second investigated criteria, the $\mathrm{E} / \mathrm{S}$ ratio was the best resulting from the former experiment, the temperature was that of the manufacture. The investigated $\mathrm{pH}$ were $6.8,7.0,7.2$, 7.4, 7.6, the experiment proceeded as described for the relative activity determination.

In the third experiment the temperature was the variable ranging from 40 to $80^{\circ} \mathrm{C}$, best $\mathrm{pH}$ and best $\mathrm{E} / \mathrm{S}$ as previously elucidated, and experiment proceeded as for determination of relative activity.

In the second set of experiments the enzyme bromelain was used on the three oilseed substrates. The sequence of experiments followed the same route as those carried with papain. The E/S investigated were 0.021 to $0.078, \mathrm{pH} 5.8,6.0,6.2$, $6.4,6.6$, and 6.8 , the temperature 35 to $50^{\circ} \mathrm{C}$.

\subsection{Analysis}

Moisture, oil, ash, fiber and nitrogen were determined according to AOCS (13) standard methods. Protein calculated as N x 6.25 for sesame and rice bran, and $\mathrm{N} \times 5.7$ for soybean.

\section{RESULTS AND DISCUSSION}

In order to carry the enzymatic degradation of the proteins in the most effective manner, optimum conditions of $\mathrm{E} / \mathrm{S}$ ratio, $\mathrm{pH}$ and temperature of the reaction were examined .Two enzymes papain and bromelain were investigated and three substrates including soybean, sesame seed and rice bran meal proteins.

Table I gives the chemical composition of the three investigated oilseed meals. All values in table are given on moisture free basis.

\subsection{Optimum conditions for the two enzymes studied}

The optimum conditions for the enzymes are expressed in terms of highest relative activity of the enzyme at different values of $\mathrm{E} / \mathrm{S}$ ratios, $\mathrm{pH}$ values, and temperatures. The time of reaction was fixed at 30 minutes to be investigated in a continuation of this study. The optimum conditions for each enzyme was determined on each substrate separately. 
Table 1

Aproximate Analysis of Oilssed Meals

\begin{tabular}{crrc}
\hline Analysis & Soybean & Sesame & Rice bran \\
\hline Oil\% & 0,9 & 0,7 & 0,5 \\
Protein\% & 43,9 & 53,4 & 12,7 \\
Ash\% & 6,6 & 6,4 & 5,9 \\
Fibre\% & 2,1 & 1,9 & 13 \\
NFE\% & 46,5 & 37,6 & 68 \\
\hline
\end{tabular}

NFE: Nitrogen free extract

All values are given on moisture free basis.

\subsubsection{Papain}

Figures 1-3 represent the relation between the relative activity of the enzyme (papain) and the investigated parameters including $\mathrm{E} / \mathrm{S}$ ratio, $\mathrm{pH}$, temperature.

- Soybean meal : optimum E/S was 0.06, optimum pH 7.2 and optimum temperature $50^{\circ} \mathrm{C}$ all resulting in highest relative activity value of 107.8 .

- Sesame meal : optimum E/S ratio $0.29, \mathrm{pH} 7.0$, temperature $50^{\circ} \mathrm{C}$, giving rise to relative activities of $175.8,81.8$, and 54.4 , respectively.

- Rice bran meal : optimum conditions were E/S ratio $0.19, \mathrm{pH} 7.0$, and temperature $50^{\circ} \mathrm{C}$, for highest relative activities 165.8, 155.5 and 164.2 , respectively.

\subsubsection{Bromelain}

Figures 4-6 demonstrates the relation between the relative activity of the enzyme (bromelain) and the investigated parameters (E/S ratio, $\mathrm{pH}$, temperature).

- Soybean meal: $\mathrm{E} / \mathrm{S}$ resulting in highest relative activity of 77.8 was 0.067 ,

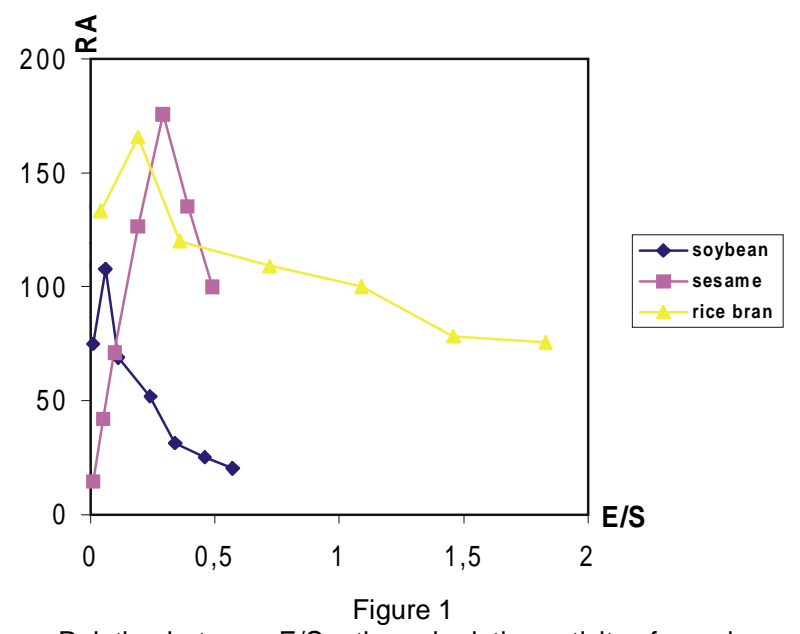

Relation between $\mathrm{E} / \mathrm{S}$ ratio and relative activity of papain

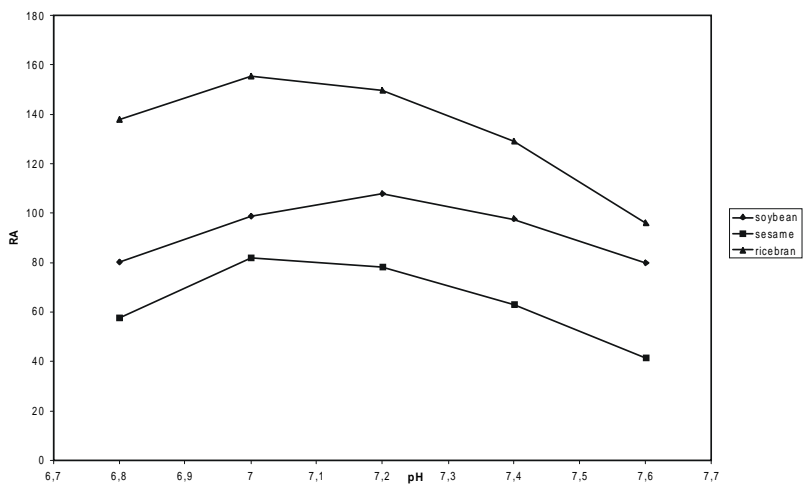

Figure 2

Effect of $\mathrm{pH}$ on relative activity of papain enzyme.

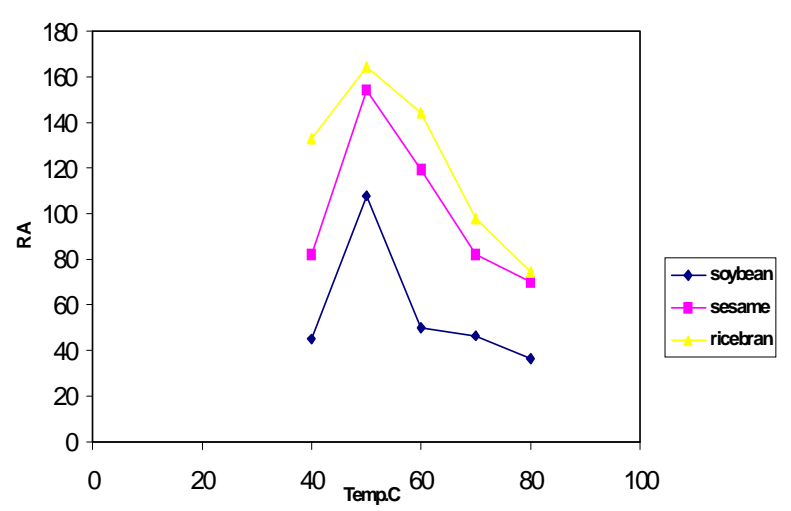

Figure 3

Effect of temperature on relative activity of papain enzyme.

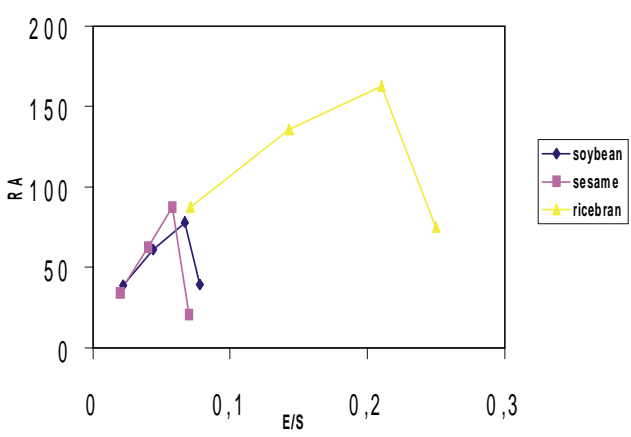

Figure 4

Relation between E//S ratio and relative activity of bromelain.

- $\mathrm{pH} 6.0$ and temperature $45^{\circ} \mathrm{C}$ gave 84.0 and 77.8 highest relative activities, respectively.

- Sesame meal : Best E/S ratio, $\mathrm{pH}$ and temperature were $0.058,6.0$, and $45^{\circ} \mathrm{C}$, 


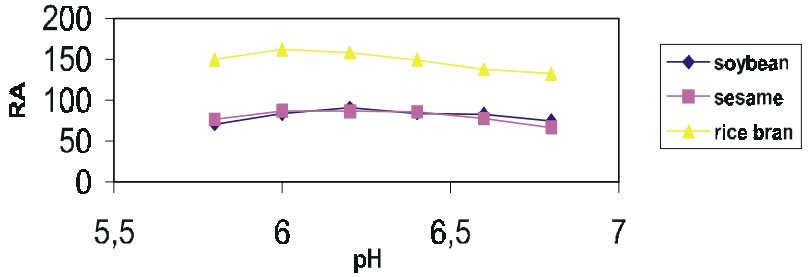

Figure 5

Effect of $\mathrm{pH}$ on relative activity of bromelain enzyme.

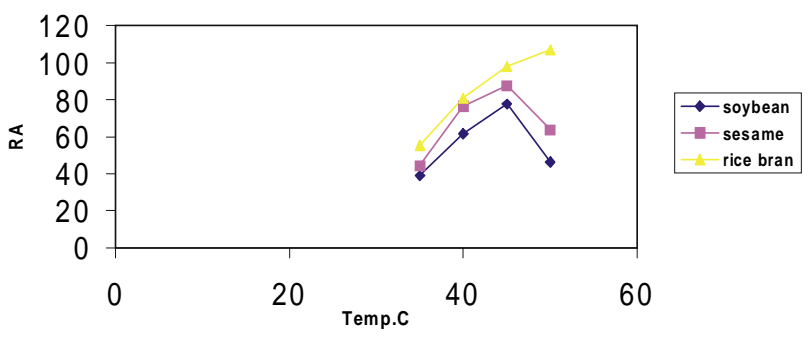

Figure 6

Effect of temp. on relative activity of bromelain enzyme.

respectively, resulting in highest relative activities 87.5 for all the parameters.

- Rice bran meal : Relative activities 162.5, 162.2, an 162.4 were attained with E/S 0.21, $\mathrm{pH} 6.0$, and temperature $45^{\circ} \mathrm{C}$, respectively.

Hermanson et al. (14), hydrolysed rapeseed protein concentrate with papain using the following conditions: $\mathrm{pH} 6.9$, temperature $65^{\circ} \mathrm{C}$ and an enzyme concentration of $0.30 \%$. Childs (15), reported optimum $\mathrm{pH}$ for papain to be 7.5 , while Sekul and Ory (3), working with peanut flour protein and papain recommended a temperature of $45^{\circ} \mathrm{C}$ and enzyme concentration $0.5 \%$. Arzu et al. (1) determining the relative activity of ten commercially available proteolytic enzymes reported relative activity of papain concentrate to be 129.1 at $\mathrm{pH} 7.2$, and the relative activity of two bacterial proteinase to be 49.5 and 58.1 at $\mathrm{pH} 6.8$.

\subsection{Numerical correlation of enzymatic behavior for different substrates}

\subsubsection{Papain}

Emperical formulae, which correlate the influencing parameters with the relative activity of papain are obtained by plotting $\mathrm{E} / \mathrm{S}$ and temperature against the relative activity on ordinary scale and conducting of regressions, the following were the results.
The relative activity is directly proportional to the $\mathrm{pH}$ of the reaction media, and is proportional exponentially with approximately $2.8 \mathrm{E} / \mathrm{S}$, in case of soybean and sesame while with approximately -0.4 $\mathrm{E} / \mathrm{S}$ in case of rice bran, and is also proportional exponentially with approximately -0.03 temperature.

Therefore in case of soybean

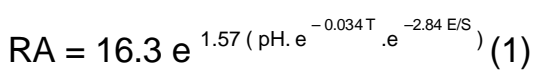

Correlation (1) is applicable within the following range:

$\mathrm{E} / \mathrm{S}=0.01-0.06$

$\mathrm{pH}=7.2-7.6$

Temperature: $50-80^{\circ} \mathrm{C}$

In case of rice bran

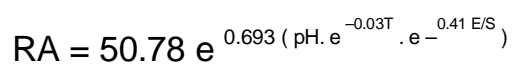

And it is applicable within the following range:

$\mathrm{E} / \mathrm{S}=0.01-1.9$

$\mathrm{pH}=7.0-7.4$

Temperature: $50-80^{\circ} \mathrm{C}$

In case of sesame

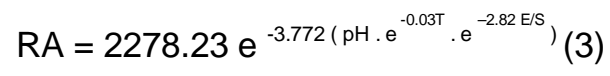

Which is applicable within the range of

$\mathrm{E} / \mathrm{S}=0.01-0.3$

$\mathrm{pH}=7.0-7.6$

Temperature $=40-80^{\circ} \mathrm{C}$

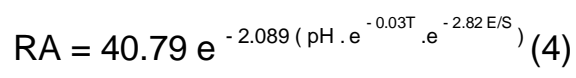

Which is applicable within the range of:

$\mathrm{E} / \mathrm{S}=0.3-0.5$

$\mathrm{pH}=7.0-7.6$

Temperature $=40-80^{\circ} \mathrm{C}$

\subsubsection{Bromelain}

Emperical formulae, which correlate the influencing parameters with the relative activity of bromelain were obtained for each substrate at certain specific ranges of those parameters.

Plotting of $\mathrm{E} / \mathrm{S}, \mathrm{pH}$ and temperature against relative activity on ordinary scale, and by conducting linear regressions, one can find that the relative activity of bromelain for each substrate ( soybean, sesame an rice bran ) is directly proportional to E/S, $\mathrm{pH}$, and temperature.

Therefore in case of soybean

$$
\mathrm{RA}=31.776 \mathrm{e}^{0.05(\mathrm{E} / \mathrm{S} \cdot \mathrm{pH} \cdot \mathrm{T})}(5)
$$

In the ranges of 
$\mathrm{E} / \mathrm{S}=0.022-0.067$

$\mathrm{pH}=6.2-6.8$

Temperature $=35-45^{\circ} \mathrm{C}$

And

$$
\mathrm{RA}=266.35-10.446(\mathrm{E} / \mathrm{S} \cdot \mathrm{pH} . \mathrm{T})(6)
$$

Correlation (6) is applicable within the following range:

$\mathrm{E} / \mathrm{S}=0.067-0.078$

$\mathrm{pH}=6.2$

Temperature: $45-50^{\circ} \mathrm{C}$

In case of rice bran

$$
\mathrm{RA}=383-4.38(\mathrm{E} / \mathrm{S} \cdot \mathrm{pH} \cdot \mathrm{T})(7)
$$

Correlation (7) is applicable within the following range:

$\mathrm{E} / \mathrm{S}=0.21$

$\mathrm{pH}=5.8-6.8$

Temperature $=35-45^{\circ} \mathrm{C}$

And

$$
\mathrm{RA}=372.62-4.17(\mathrm{E} / \mathrm{S} \cdot \mathrm{pH} . \mathrm{T})(8)
$$

Correlation (8) is applicable within the following range:

$\mathrm{E} / \mathrm{S}=0.21-0.25$

$\mathrm{pH}=6.0$

Temperature $=45-50^{\circ} \mathrm{C}$

In case of sesame

$$
\mathrm{RA}=6.22-5.845(\mathrm{E} / \mathrm{S} \cdot \mathrm{pH} . \mathrm{T})(9)
$$

Correlation (9) is applicable within the following ranges :

$\mathrm{E} / \mathrm{S}=0.02-0.058$

$\mathrm{pH}=5.8-6.0$

Temperature $=40^{\circ} \mathrm{C}$

$$
\mathrm{RA}=234.78-10.35(\mathrm{E} / \mathrm{S} \cdot \mathrm{pH} . \mathrm{T})(10)
$$
range:

Correlation (10) is applicable within the following

$\mathrm{E} / \mathrm{S}=0.058$

$\mathrm{pH}=6.0-6.8$

Temperature $=40^{\circ} \mathrm{C}$

And

$$
\mathrm{RA}=198.213-7.858(\mathrm{E} / \mathrm{S} \cdot \mathrm{pH} \cdot \mathrm{T})(11)
$$

Correlation (11) is applicable within the following range:

$\mathrm{E} / \mathrm{S}=0.058$

$\mathrm{pH}=6.0-6.8$

Temperature $=40-45^{\circ} \mathrm{C}$
The relative activity of papain and bromelain calculated from the above emperical formulae were in fair agreement with those obtained from experimental work, and the mean standard errors for each enzyme were within the $\pm 10 \%$ as shown in (Figures 7 and 8).

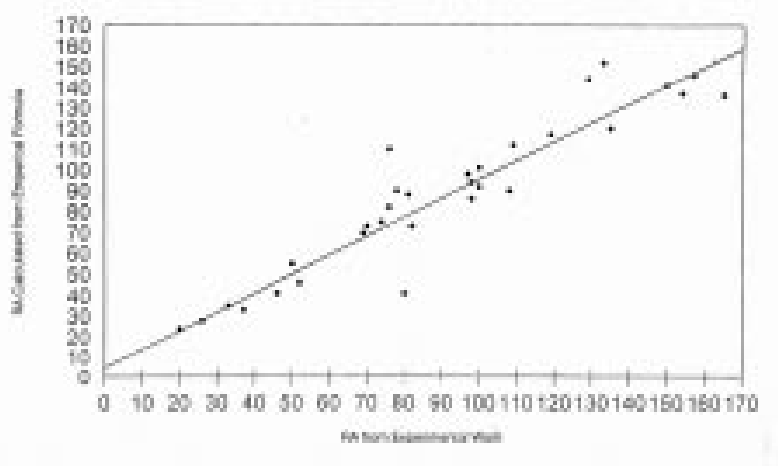

Figure 7

The relationship between experimentally calculated RA \& emperically calculated RA of papain at different substrates.

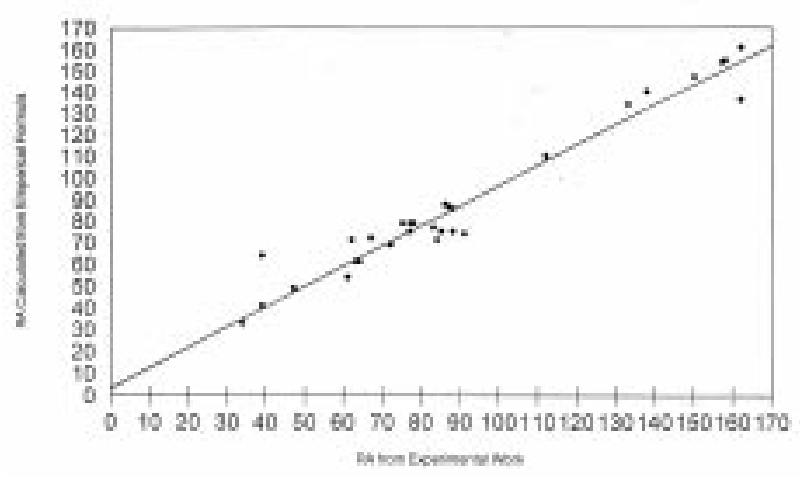

Figure 8

The relationship between experimentally calculated RA \& emperically calculated RA of bromelain at different substrates.

\section{REFERENCES}

1. Arzu, A., Mayorga,H., Gonzales, J. and Rolz. C. (1972). Enzymatic Hydrolysis of Cottonseed Protein. J. Agric Food Chem. 20, 805-809 .

2. Adler-Nissen, J. (1976). Enzymatic Hydrolysis Of Protein For Increased Solubility. J. Agric Food Chem. 24, 1090-093.

3. Sekul, A.A. and Ory, L. (1977). Rapid Enzymatic Method for Partial Hydrolysis of Oilseed Proteins for Food Uses. J. Amer. Oil Chem. Soc. 54, 32-35.

4. Cunningham, S.D., Cater, C.M. and Mattil, K.F. (1978). Cottonseed Modification in an Ultrafiltration Cell. J. Food Sci. 43, 1477-1480.

5. Jones, L.J. and Tung, M.A. (1983). Functional Properties of Modified Oilseed Concentrates and Isolates. Can Inst. Food Sci. Technol. 16,57-62. 
6. Steinhart, H. (1973). The Course of Reaction of Hydrolysis of Isolated Soybean with Papain. Zeitschrift Fuer Lebensmittel -Untersuchumg Und Forshung 152, 332-335.

7. Roozen, I.P. and Pilnik, W. (1974). Improvement of Acid Solubility of Soy Protein by Enzymatic Hydrolysis and its Influence on Their Taste Properties. Deutsche Lebensmittel Runschau 70, 280-283.

8. Pour- El, A. and Swenson, T.S. (1976). Gelation Properties of Enzymatically Modified Soy Protein Isolates. Cereal Chem. $53,438-456$.

9. Paulson,A.T., Tung, M.A., Garland, M.R. and Nakai, S. (1984). Functionality of Modified Plant Proteins in Model Systems. Canad. Inst. Food Sci. Technol. 17, 202-208.

10. Perez, G.C. and Saad, L.R. (1984). Enzymic Modification of Protein of Commercial Sesame Seed Meal. Archivos Latinoamericano De Nutricion 34, 735-748.

11. Saad, L.R. and Perez, G.C. (1984). Functional and Nutritional Properties of Modified Sesame Seed
Protein. Archivos Latinoamericano De Nutricion 34, 749-762

12. Mahmoud, M.I. (1994). Physico-Chemical and Functional Properties of Protein Hydrolysates in Nutritional Products. Food Technol. 48, 89-95.

13. AOCS "Official Methods and Recommended Practices" of the American Oil Chemist's Society, 5 th edition, Champaign, IL, 1998.

14. Hermanson, A.A., Olson, D. and Holmberg, B.(1974). Functional Properties of Proteins for Foods Modification of Rapeseed Protein Concentrate. Lebens Wissu U Technol. 7, 176-181.

15. Childs, E.A. (1975). An Enzymatic Chemical Method for The Extraction of Cottonseed Protein. Food Sci. 40, 78-80.

Recibido: Febrero 2001 Aceptado: Diciembre 2001 